2 Waxveiler RJ, Beaumont JJ, Henry JA, Brown DP, Robinson CF, Ness GO, et al. A modified life-table analysis system for cohort studies. F Occup Med 1983;25:115-24

3 World Health Organisation. Proposal for the multinational monitoring of trends and determinants in cardiovascular disease and protocol (MONICA project). Geneva: WHO, 1983. (WHO/MNC/82.1)

4 Tunstall-Pedoe $H$. Diagnosis, measurement and surveillance of coronary events. Int F Epidemiol 1989;18:169-73.

5 Tuomilehto J, Kuulasmaa K. WHO MONICA project: assessing CHD mortality and morbidity. Int $\mathcal{F}$ Epidemiol 1989;18(3 suppl 1):38-45S.

6 Thorgeirsson G, Davidsson D, Sigvaldason H, Sigfusson N. Major risk factors for coronary heart disease mortality in Icelandic women. Eur Heart $f$ $1990 ; 11: 326$.

Block WD, Jarrett KJ, Levine JB. An improved automated determination of serum total cholesterol with single color reagent. Clin Chem 1966;10:681-9.

8 Rose GA, Blackburn H. Cardiovascular survey methods. Geneva: World Healt Organisation, 1968:160-2.

Cox DR. Regression models and life tables. Journal of the Royal Statistical Society 1972;34[B]:187-220.

10 Ragnarsson JO, Stefansdottir E. Icelandic nutritional survey 1979-1980. RALA report. Revkjavik: Agricultural Research Institute, 1981:74.

11 Agricultural Production Board. Arbok landbunadarins [Icelandic agricultural yearbook l. Reykjavik: APB, 1970, 1975, 1980, 1985, 1987.

12 Statistical Bureau of Iceland. Hagtidindi. Idnadarvöruframleidsla [A monthly statistical bulletin. Industrial production.] Reykjavik: SBI, 197156 (12) statistical bul

13 Breslow NE, Day NE. Statistical methods in cancer research. Vol 1. The analysis of case-control studies. Lyons: International Agency for Research on Cancer, 1980. (IARC Scientific Publications, No 32.

\section{Excess mortality associated with the HIV epidemic in England and Wales}

\section{Anna McCormick}

Office of Population Censuses and Surveys, London WC2B 6JP Anna McCormick, FFPHM, senior medical statistician

$B M \mathcal{F} 1991 ; 302: 1375-6$
14 Breslow NE, Day NE. Statistical methods in cancer research. Vol 2. The design and analysis of cohort studies. Lyons: International Agency for Research on Cancer, 1980. (IARC Scientific Publications, No 32 .)

15 Segi M. Cancer mortality for selected sites in 24 countries (1950-1957). Sendai: Toun

16 Muttiple Risk Factor Intervention Trial Research Group. Multiple risk factor intervention trial; risk factor changes and mortality results. JAMA 1982; 248:1465-77.

17 Hilmarsdottir E, Valdimarsson G, Thorkelsson G. Innlend matvaelaframleidsla [Domestic food production]. In: Manneldi og nevsla. Reykjavik: Ministry of Health and Social Security, 1989:155-88

18 Rifkind BM. Clinical trials of cholesterol lowering. Atherosclerosis Review 1988;18:59-70.

19 Keys A, Anderson J, Grande F. Serum cholesterol response to dietary fat Lancet $1957 ;$; 7887 .

20 Dobson AJ. Trends in cardiovascular risk factors in Australia, 1966-1986: evidence from prevalence surveys. Community Health Stud 1987;11(1):2-14.

21 Sytkowski PA, Kannel WB, D'Agostino RB. Changes in risk factors and the decline in mortality from cardiovascular disease. The Framingham hean study. N Engl f Med 1990;322:1635-41.

22 Dwyer T, Hetzel BS. A comparison of trends of coronary heart disease mortality in Australia, USA and England and Wales with reference to three major risk factors-hypertension, cigarette smoking and diet. Int f Epidemiol 1980:9:65-71.

23 Beaglehole R, Hay DR, Foster FH, Sharpe DN. Trends in coronary heart disease mortality and associated risk factors in New Zealand. $N Z$ Med $\mathcal{F}$ 981;93:371-5.

(Accepted 15 March 1991)
Increased mortality unattributed to but probably associated with HIV infection has been reported in the United States. ${ }^{1.3}$ Excess mortality has also been identified among HIV positive haemophiliac patients in the United Kingdom. ${ }^{4}$ A study of trends in mortality between 1984 and 1987 suggested that the increase found among single men was probably related to HIV infection. ${ }^{5}$ In this paper I examine the number of excess deaths in England and Wales in 1988 and 1989 and relate this to the HIV epidemic.

\section{Patients, methods, and results}

Draft death entries on which one of 95 selected conditions was stated to be the cause of death were identified at the Office of Population Censuses and Surveys (OPCS). These causes were selected because they had been mentioned on death certificates of people known to have had AIDS. They included 86 medical causes, including AIDS and HIV infection (International Classification of Diseases (ICD) code 279.1). Nine external causes were also included, covering drug dependence and poisoning due to various substances. The number of excess deaths was estimated by subtracting the number of deaths in 1984 from the number in each subsequent year after adjusting for population changes within each five year age group. The numbers of reports of people who died with AIDS and HIV positive people who died without developing an AIDS indicator disease were obtained from the Public Health Laboratory Service Communicable Disease Surveillance Centre (CDSC).

There were 2505 deaths due to one of the 95 causes among single men aged $15-54$ in $1989-498(25 \%)$ above the number expected based on rates in 1984 . AIDS or HIV infection was stated as the cause of death for only $233(47 \%)$ of the excess deaths, leaving 265 (53\%) probable HIV related deaths attributed to some other cause.

Analysis of the 86 medical causes alone showed that there were 1362 deaths among single men aged 15-54 in
1989-379 (39\%) above the number expected -233 $(61 \%)$ of which were attributed to AIDS or HIV infection. There was no similar increase among men of other marital states or among women. The increase was greatest among single men aged 30-44 and in the Thames health regions.

Analysis of the nine external causes alone, however, showed a different picture. Among single men aged $15-54$ there were 1143 deaths in $1989,119(12 \%)$ above the number expected compared with 1984. Smaller increases also occurred among men of other marita states and among women. The increase among single men was greatest among those aged 15-24 and was fairly evenly distributed across the country, suggesting that factors other than the HIV epidemic may have contributed.

In all, 376 deaths among HIV positive single men aged 15-54 were reported to CDSC in 1989, an excess of 347 compared with 1984 . If the total number of deaths reported to OPCS is used as the denominator $70 \%$ were reported to CDSC in 1989 . However, if deaths reported to OPCS due to the 86 medical causes alone is used $92 \%$ were reported to CDSC.

\section{Comment}

The associations with age, sex, marital state, and geographic location suggest that the continuing increase in the number of deaths due to the $86 \mathrm{HIV}$ related

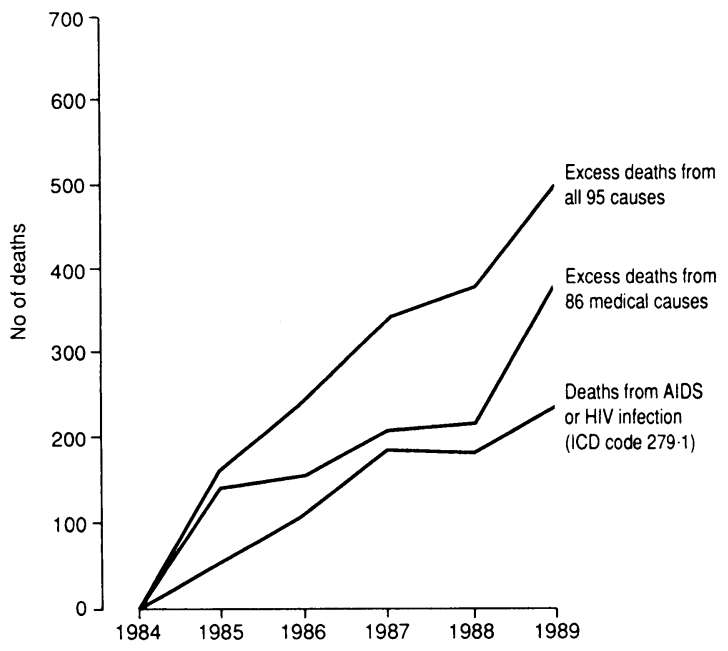

Number of excess deaths due to HIV related causes and of deaths from AIDS or HIV infection in single men aged 15-54 in England and Wales during 1985-9 compared with rates in 1984 
medical causes in this country is associated with HIV infection. The contribution of HIV to the smaller increase in the number of deaths due to external HIV related causes is more tenuous and requires further investigation. This could include testing for HIV in people who die of or receive medical care for these conditions. Accurate diagnosis and more complete reporting are required if the full extent of the HIV epidemic is to be identified.

I thank my colleague Tim Devis, statistician, for his help in extracting mortality data.

1 Buehler J, Berkelman R, Devine O, Chevarley F. Impact of the human immunodeficiency virus epidemic on mortality trends in young men, United States. Am f Public Health 1990;80:1080-6.

2 Centers for Disease Control. Increase in pneumonia mortality among young adults and the HIV epidemic. $M M W R$ 1988;37:593-6.

3 Marzuk PM, Tierney H, Tardiff K, Gross EM, Morgan EB, Hsu M-A, et al. Increased risk of suicide in persons with AIDS. FAMA 1988;259:1333-7.

4 Darby SC, Rizza CR, Doll R, Spooner RJD, Stratton IM, Thakrar B. Incidence of AIDS and excess mortality associated with HIV in haemophiliacs in the United Kingdom: report on behalf of the directors of haemophilia centres in the United Kingdom. BMF 1989;298:1046-8.

5 McCormick A. Trends in mortality statistics in England and Wales with particular reference to AIDS from 1984 to April 1987. BMF 1988;296: 1289-92.

(Accepted 18 April 1991)

\section{HIV surveillance: the value of audit}

\section{Matthew Hickman, John Aldous, John Porter, Linda Durman}

Department of Public

Health, Riverside Health

Authority, London

SW6 4UL

Matthew Hickman, BSC,

district HIV information

officer

John Aldous, MRCGP,

registrar in public health

medicine

Linda Durman, MFPHM,

director of public health

Public Health Laboratory

Service Communicable

Disease Surveillance

Centre, London NW9 5EQ

John Porter, MFPHM

consultant in public health

medicine

Correspondence to: $\mathrm{Mr}$

Hickman.

BMF 1991:302:1376-7
Surveillance of the HIV epidemic in England and Wales relies on two national voluntary reporting systems run by the Public Health Laboratory Service Communicable Disease Surveillance Centre: one for cases of AIDS, the other for positive results of HIV antibody tests. The Communicable Disease Surveillance Centre collates this information and identifies duplicate reports to form anonymised national databases of cases of AIDS and patients positive for HIV. In future this form of surveillance will be supplemented by the unlinked anonymous testing programme.

Although several studies have shown underreporting of cases of AIDS, ${ }^{2-4}$ little is known of the effectiveness of the national surveillance of results of tests for HIV antibody. We evaluated the reporting of these results from Riverside Health Authority.

\section{Subjects, methods, and results}

We identified 14 sources of information on people infected with HIV in the district (table). From July to September 1989 we collected data from these sources, entered them on to a computerised database, and cross checked them for duplicate reporting. We reviewed case notes if there were insufficient data to identify duplicate reports or to confirm HIV infection if the result of an HIV antibody test had not been recorded. If case notes were unobtainable or contained no record of HIV infection we removed that record from the database.

We compared the number of subjects with a positive result of an HIV antibody test performed in the district with the number attributed to the district by the national surveillance system up to July 1989.
The study identified 2867 people with HIV infection (table); 2808 had a record of a positive result of an HIV antibody test performed in the district. The Communicable Disease Surveillance Centre had records of 1861 people with a positive result reported from Riverside. Therefore 947 either had not been reported or had been first reported from another district health authority.

In Riverside one laboratory did not report positive test results to the Communicable Disease Surveillance Centre, and one genitourinary clinic used a reference laboratory for primary testing for HIV antibody which also did not report its positive results. Together these sources were responsible for 621 of the positive results identified by this study. We reported test results from these two sources to the Communicable Disease Surveillance Centre, which accepted 617 as being reported for the first time and retrospectively incorporated them into the national figures. This increased the number of people with a positive test result attributed to Riverside by $33 \%$ and the total for England and Wales by $6 \%$. The remaining positive results were checked further by the Communicable Disease Surveillance Centre to identify any that had not been reported previously.

\section{Comment}

Underreporting of positive results of HIV antibody tests reduces the usefulness of the national surveillance system as a means of monitoring changes in the HIV epidemic and of planning effective prevention strategies. This study showed that between $22 \%$ and $34 \%$ of the positive results of tests performed in Riverside had not been reported to the Communicable Disease Surveillance Centre. Although this scale of underreporting may be peculiar to Riverside, we recommend that all health authorities should audit their reporting of positive results. An essential first step is to ensure that each laboratory undertaking primary testing for HIV antibody is reporting to the national surveillance system.

Furthermore, it is important that laboratories

Sources of data used in Riverside Health Authority

\begin{tabular}{|c|c|c|c|}
\hline & No of data sources & Type of data source & No of records \\
\hline Genitourinary clinic & $\begin{array}{l}2 \\
1 \\
1 \\
1\end{array}$ & $\begin{array}{l}\text { Computerised database of patients with HIV infection } \\
\text { File register of patients with HIV infection } \\
\text { List of patients with HIV infection in } 1987 \\
\text { List of cases of AIDS reported to Communicable Disease Surveillance Centre }\end{array}$ & $\begin{array}{r}2300 \\
457 \\
193 \\
226\end{array}$ \\
\hline Microbiology laboratory & $\begin{array}{l}1 \\
2\end{array}$ & $\begin{array}{l}\text { Computerised database of tests for HIV antibody } \\
\text { Register of tests for HIV antibody }\end{array}$ & $\begin{array}{r}1923 \\
664\end{array}$ \\
\hline Hospital inpatients & $\begin{array}{l}1 \\
1 \\
1 \\
1\end{array}$ & $\begin{array}{l}\text { Patient administration system } \\
\text { Hospital ward book } \\
\text { List of inpatients with HIV infection } \\
\text { List of cases of AIDS reported to Communicable Disease Surveillance Centre }\end{array}$ & $\begin{array}{l}215 \\
156 \\
160 \\
119\end{array}$ \\
\hline Other & $\begin{array}{l}1 \\
1\end{array}$ & $\begin{array}{l}\text { List of patients with HIV infection in } 1985 \\
\text { Computerised database of death certificates }\end{array}$ & $\begin{array}{r}32 \\
288\end{array}$ \\
\hline $\begin{array}{l}\text { No of records collected } \\
\text { No of duplicates } \\
\text { No of people with HIV in }\end{array}$ & & & $\begin{array}{l}6733 \\
3866 \\
2867\end{array}$ \\
\hline
\end{tabular}

I

